\title{
Nitrite Reduction Enhancement on Semiconducting Electrode Decorated with Copper(II) Aspirinate Complex
}

\author{
Fabiana A. Sayão ${ }^{1}$ - Jader Barbosa da Silva Flor ${ }^{1} \cdot$ Regina Célia Galvão Frem ${ }^{1}$. \\ Simone Stulp ${ }^{2} \cdot$ Juliano C. Cardoso $^{1} \cdot$ Maria V. B. Zanoni ${ }^{1}$
}

Published online: 10 September 2016

(C) Springer Science+Business Media New York 2016

\begin{abstract}
The present work seeks to describe a new approach characterized by copper(II) aspirinate complex deposited onto nanotube $\mathrm{TiO}_{2}$ electrodes as mediator of electron transfer during nitrite reduction, aiming at achieving a faster removal of nitrite to nitrogen species oxides. Thin films of copper aspirinate $\left(\left[\mathrm{Cu}_{2}(\mathrm{asp})_{4}\right]\right)$ on the $\mathrm{Ti} / \mathrm{TiO}_{2}$ nanotube surface are easily obtained following multi-scans (100 cycles) recorded for the $\mathrm{Ti} / \mathrm{TiO}_{2}$ electrode in $0.1 \mathrm{~mol} \mathrm{~L}^{-1} \mathrm{NaCl}, \mathrm{pH} \mathrm{4}$, containing $5.0 \times$ $10^{-4} \mathrm{~mol} \mathrm{~L}^{-1}$ of the copper coordination compound. The complex showed high adherence while the cyclic voltammograms presented redox peaks at $-0.15 /+$ $0.15 \mathrm{~V}$, which was attributed to the reduction of $\mathrm{Cu}(\mathrm{II})$ to $\mathrm{Cu}(\mathrm{I})$. Following 5 min of treatment using photoelectrocatalysis on $\mathrm{Ti}^{-} / \mathrm{TiO}_{2}-\left[(\mathrm{Cu})_{2} \mathrm{Asp}_{4}\right]$ electrode, a total removal of nitrite was observed, which was found to be at least four times faster compared to Ti/ $\mathrm{TiO}_{2}$ electrode. Concomitantly, we also observed a relatively good conversion to nitrogen-containing gaseous species $(56 \%)$ besides the formation of $42 \%$ of ammonia. The results, in effect, also indicate that nitrate and nitrite are not detectable in the treated solution up to levels of $0.5 \mathrm{mg} \mathrm{L}^{-1}$. The method under consideration has successfully accounted for the maximum limit of nitrite recommended in drinking water which has been set to $1 \mathrm{mg} \mathrm{L}^{-1}$.
\end{abstract}

Maria V. B. Zanoni

mvboldrin@gmail.com

1 Instituto de Química de Araraquara, Universidade Estadual Paulista "Júlio de Mesquita Filho" (UNESP), R. Prof. Francisco Degni, 55, P.O. Box 355, 14800-900 Araraquara, SP, Brazil

2 Centro Universitário Univates, Rua Avelino Tallini, Bairro Universitário, 171, CEP 95900-000 Lajeado, RS, Brazil
Keywords Nitrite removal · Photoelectrocatalysis reductive process $\cdot$ Copper(II) aspirinate complex $\cdot$ Photoelectrocatalytic reduction of nitrite

\section{Introduction}

It is universally accepted that the water treatment process is largely effective to obtain water suitable for human consumption, once the required physical, chemical, and biological parameters are controlled and accounted for [1]. Nonetheless, notwithstanding the use of multiple steps in the water treatment procedures currently in use, the methods for removal of inorganic anions are found to be scarce while there is a consensus that some of them can be harmful to the environment and human health. Maximum limits have been set out concerning the amount of inorganic substances tolerable in portable water as a way to undermine any potential hazardous risk that they may pose to human health among them including $1.00 \mathrm{mg} \mathrm{L}^{-1}$ for nitrite $\left(\mathrm{NO}_{2}^{-}\right)$and nitrate [2-4]. A major concern has been widely raised regarding the control of nitrite ions vis-à-vis the health risk they pose primarily owing to the fact that these ions are known to be the precursor of methemoglobinemia disease and of the formation of carcinogenic nitrosamines [3-5]. While biological denitrication is found to be the most important alternative when it comes to the removal of nitrate from drinking water, it has become a general consensus that nitrite is likely to be formed during the process [2-4]. Although it is true that several methods for nitrate removal have been proposed in the literature [6, 7], methods associated with the removal of nitrite are surprisingly a huge rarity [8-10]. 
The use of photoelectrocatalysis in water treatment has attracted a wider attention in recent times [11-15]. The essence of the technique lies within the separation of photogenerated $\mathrm{e}^{-} / \mathrm{h}^{+}$pairs when the semiconductor is irradiated with UV light and a potential gradient [6]. The possibility of generating electrons, holes, hydroxyl radicals, and/or superoxide radicals has dramatically increased the application of photoelectrocatalysis over the last years. Most of these studies are based on oxidative process involving hydroxyl radical as potent oxidant. Admittedly, few authors have indicated that the use of $\mathrm{TiO}_{2}$ can be a suitable cathode material for promoting reduction reaction on the irradiated electrode [16-18]. The most relevant works have indicated that nitrate can be reduced on $\mathrm{Cu} / \mathrm{Cu}_{2} \mathrm{O}$ [16], while bromate can be converted to bromide on $\mathrm{Ti} / \mathrm{TiO}_{2}$ solgel thin film at a neutral $\mathrm{pH}$ under an applied potential of $-0.20 \mathrm{~V}$ following $75 \mathrm{~min}$ of irradiation [17]. Furthermore, nitrite can be reduced on $\mathrm{TiO}_{2}-\mathrm{NT}$ as photocathode under UV irradiation and applied potential of $-0.2 \mathrm{~V}$ vs $\mathrm{Ag} / \mathrm{AgCl}$ [19].

The progress of photoelectrocatalysis can be said to be intrinsically related to the advances in material science, and a huge attention has been devoted, in recent times, towards the decoration and coating of $\mathrm{TiO}_{2}$ nanotubes with compounds capable of increasing the electrocatalytic performance [20-22]. It is noteworthy that a chemically modified semiconductor with redox system can photoinduce electron transfer reaction improving the photochemical processes [23, 24]. When a complex such as $\left[\mathrm{Ru}(\mathrm{bpy})_{3}\right]^{2+}$ is bound to the photoelectrode, the electron transfer quenching reaction can contribute towards accelerating the photochemical process [24]. A similar behavior is also observed for a semiconductor $\left(\mathrm{N}-\mathrm{Ta}_{2} \mathrm{O}_{5}\right)$ modified with a metal complex such as $[\mathrm{Ru}-$ dcbpy]. The photoexcited electrons are transferred from the conduction band of the semiconductor to the metallic complex that can act as electrocatalyst, leading to $\mathrm{CO}_{2}$ reduction with great success [23].

Thus, the present work investigates the decoration of nanotube $\mathrm{Ti} / \mathrm{TiO}_{2}$ with copper(II) aspirinate complex (see chemical structure in Fig. 1) with the aim of improving the removal of nitrite from aqueous solution by means of the photoelectrocatalytic method. Copper aspirinate, $\left[\mathrm{Cu}_{2}(\operatorname{asp})_{4}\right]$, is a potent antioxidative agent with superoxide scavenging activity [25] which could improve the photocatalytic performance of the semiconductor when applied in a reductive process. This copper(II) compound can be synthesized by a simple and fast way with low cost $(\sim 0.020 / \mathrm{g}$ of aspirin $)$ and great versatility to be used as a multifunctional thin film coating. The photoconversion feasibility of nitrite to nitrogen has been evaluated through total nitrite removal as well as nitrate and ammonia formation so as to assess the effectiveness of the proposed method.<smiles>CC(=O)Oc1ccccc1C1OC(c2ccccc2OC(C)=O)OC2(O1)OC(c1ccccc1OC(C)=O)OC(Cl)(OC(OC(C)=O)c1ccccc1OC(C)=O)C(c1ccccc1OC(C)=O)O2</smiles>

Fig. 1 Chemical structure of $\mathrm{Cu}$ (II) aspirinate complex

\section{Experimental}

\section{Chemicals and Synthesis of the Copper(II) Coordination Compound}

Ultra-pure reagents were purchased from Merck, and purified water derived from a Millipore Milli-Q system (resistivity $18.2 \mathrm{~m} \Omega \mathrm{cm}, \mathrm{pH} 6.9$ ) was used in the preparation of all solutions. The supporting electrolyte used in the photoelectrochemical measurements was $0.015 \mathrm{~mol} \mathrm{~L}^{-1}$ $\mathrm{NaCl}$ solution (Sigma). Sodium nitrite (Sigma) solution of $0.23,0.46,1.15$, and $2.30 \mathrm{~mol} \mathrm{~L}^{-1}$. Copper(II) aspirinate complex, $\left[\mathrm{Cu}_{2}(\mathrm{asp})_{4}\right]$, was prepared as follows: briefly, $4.5 \mathrm{~g}$ of acetylsalicylic acid (previously extracted from aspirin tablets with hot isopropyl alcohol/ice-cold water) was suspended in $50 \mathrm{~mL}$ of distilled water. The solution was stirred at $60{ }^{\circ} \mathrm{C}$ by magnetic stirring. Afterwards, about $1.5 \mathrm{~g}$ of solid copper(II) carbonate was slowly added. At the end of the addition of the copper salt, the system was allowed to stay for $15 \mathrm{~min}$ prior to filtration. The greenish blue crystals were washed with ice-cold distilled water and dried at room temperature. The structure of the $\left[\mathrm{Cu}_{2}(\operatorname{asp})_{4}\right]$ was confirmed using X-ray and elemental analyses while subjected to comparison with reports in the literature $[25,26]$.

\section{Apparatus}

All electrochemical measurements were performed using a Potentiostat/Galvanostat AUTOLAB, PGSTAT 302 model controlled by NOVA 1:10 software. The $\mathrm{pH}$ measurements were performed on a $\mathrm{pH}$ meter TECNOPON, mPa 210 model with combined glass electrode. Nitrite, nitrate, and chloride were analyzed by ionic chromatograph using an ion chromatograph Dionex ICS-100 using a 23 ionPac $®$ column with AG23 guard column. The chosen eluent was $4.5 \mathrm{mmol} \mathrm{L}^{-1}$ buffer $\mathrm{Na}_{2} \mathrm{CO}_{3} / \mathrm{NaHCO}_{3}$; flow rate $0.25 \mathrm{~mL} \mathrm{~min}{ }^{-1}$; injection volume $75 \mu \mathrm{L}$. Calibration curves for nitrite, nitrate, and chloride were obtained from 0.25 to $100 \mathrm{mg} \mathrm{L}^{-1}$. Samples of 
treated nitrite solutions were injected directly without any pretreatment of the sample. The spectrophotometric measurements were performed in a spectrophotometer coupled to diode array BEL UV-M51 interfaced in a UV-Professional program. All measurements were performed using quartz cuvettes of $1.0 \mathrm{~cm}$ optical path.

The ammonium generation was monitored using colorimetric kits for the detection of ammonium Merck (Ammonium-Test Kit 1.14752.0001 Spectroquant ${ }^{\circledR}$ ). The test is based on the reaction between ammonia, chloramine, and thymol forming a blue derivative product detected at $690 \mathrm{~nm}$.

The products generated from the photoelectrocatalytic reduction of nitrite were expressed as $\%$ of generation $=(\mathrm{mol}$ product formed) $/ \mathrm{mol}$ nitrite consumed) $\times 100$. The $\%$ of nitrogen-containing gaseous species (i.e., $\mathrm{N}_{2}, \mathrm{NO}$, and $\mathrm{NO}_{2}$ ) was calculated considering that all of the amount of nitrite consumed and not detected as ammonia was converted to nitrogen-containing gaseous species [8-10].

\section{Nanotube $\mathrm{Ti} / \mathrm{TiO}_{2}$ Electrodes With and Without Coating With $\left[\mathrm{Cu}_{2}(\mathbf{a s p})_{4}\right]$}

The nanotube (NT) electrodes of $25 \mathrm{~cm}^{2}$ of geometric area were made through the anodization of titanium foil, previously polished and cleaned, using a two-electrode cell, where the Ti foil was used as anode while a platinum net of $10 \mathrm{~cm}^{2}$ of geometric area as cathode. The anodization was conducted at a constant voltage of $30 \mathrm{~V}$ for $50 \mathrm{~h}$ in a solution of $0.25 \mathrm{wt} . \%$ $\mathrm{NH}_{4} \mathrm{~F}$ with glycerol and water $(90: 10, v / v \%)$. Finally, the photoelectrode was subjected to fire at $450{ }^{\circ} \mathrm{C}$ for $30 \mathrm{~min}$ in a muffle oven (EDG 3P-S) [27, 28].

The immobilization of the $\left[\mathrm{Cu}_{2}(\mathrm{asp})_{4}\right]$ on the $\mathrm{Ti} / \mathrm{TiO}_{2}$ nanotube electrode was carried out using the following procedures. The cleaned electrode was introduced into an electrochemical cell containing a solution of $5 \times 10^{-4} \mathrm{~mol} \mathrm{~L}^{-1}$ of complex in $0.1 \mathrm{~mol} \mathrm{~L}^{-1} \mathrm{NaCl}$ at $\mathrm{pH} 4$, where oxygen was removed by bubbling nitrogen gas for $10 \mathrm{~min}$. The electrode was subjected

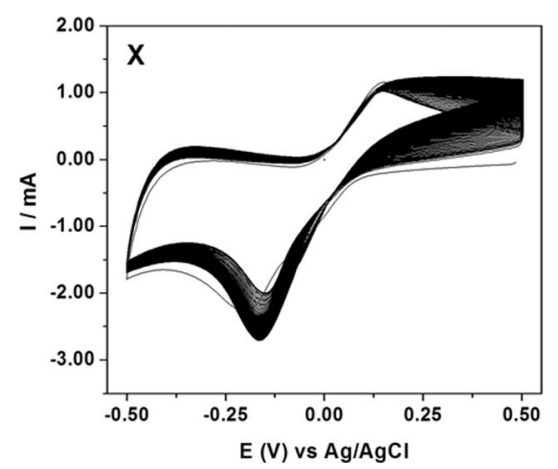

Fig. 2 Curve $X$ : cyclic voltammograms obtained during successive scan (100 cyles) for $5 \times 10^{-4} \mathrm{~mol} \mathrm{~L}^{-1}$ of $\left[\mathrm{Cu}_{2}(\operatorname{asp})_{4}\right]$ in BR buffer $0.1 \mathrm{~mol} \mathrm{~L}^{-1}$ $\mathrm{pH} 4$ at Ti/ $/ \mathrm{TiO}_{2}-\mathrm{NTs}$ electrode, $=100 \mathrm{mV} \mathrm{s}^{-1}$. Curve $Y$ : comparison of to cycling in the potential range of +0.5 to $-0.5 \mathrm{~V}$ under a scan rate of $100 \mathrm{mV} \mathrm{s}^{-1}$ (100 cycles). Voltammograms (+0.5 to $-0.5 \mathrm{~V}$ ) were performed on the electrode with and without modification of $\left[\mathrm{Cu}_{2}(\mathrm{aps})_{4}\right]$ complex transferred to a $\mathrm{NaCl}$ solution $\left(0.015 \mathrm{~mol} \mathrm{~L}^{-1}\right)$ at $\mathrm{pH} 7$ under and without $\mathrm{UV} / \mathrm{Vis}$ irradiation, at $\nu=50 \mathrm{mV} \mathrm{s}^{-1}$.

The morphological characterization was carried out by field emission gun-scanning electron microscopy (FEGSEM) with a JEOL 7500F microscope. The optical properties were evaluated by diffuse reflectance spectroscopy (DRS), using an UV/Vis/NIR spectrometer (PerkinElmer Lambda 1050 ) with an integrating sphere- $150 \mathrm{~mm} \mathrm{UV/Vis/NIR}$ (InGaAs) module. The equipment was calibrated with a Spectralon standard (Labsphere USRS-99-020, $99 \%$ reflectance), and the reflectance was measured in the range of 250 $800 \mathrm{~nm}$. The electronic properties of $\mathrm{Ti} / \mathrm{TiO}_{2}$ and $\mathrm{Ti} /$ $\mathrm{TiO}_{2}-\left[\mathrm{Cu}_{2}(\mathrm{asp})_{4}\right]$ electrodes were evaluated by photocurrent curves by linear sweep voltammetry $(+0.2$ to $-1.5 \mathrm{~V})$ technique at $\nu=10 \mathrm{mV} \mathrm{s}^{-1}$ in $0.015 \mathrm{~mol} \mathrm{~L}^{-1} \mathrm{NaCl}$ solution (Sigma-Aldrich), under dark and UV/Vis irradiation. In addition, the electronic properties of $\mathrm{Ti} / \mathrm{TiO}_{2}$ and $\mathrm{Ti} / \mathrm{TiO}_{2}-\left[\mathrm{Cu}_{2}(\text { asp })_{4}\right]$ electrodes in the presence of $1.15 \mathrm{~mol} \mathrm{~L}^{-1}$ nitrite were evaluated by photocurrent curves through linear sweep voltammetry $(0.0$ to $-1.0 \mathrm{~V})$ at $\nu=10 \mathrm{mV} \mathrm{s}^{-1}$ in $0.015 \mathrm{~mol} \mathrm{~L}^{-1}$ $\mathrm{NaCl}$ solution, under dark and $\mathrm{UV} / \mathrm{Vis}$ irradiation.

\section{Photoelectrocatalytic Reactor}

The photoelectrocatalytic (PEC) experiments were performed in a $250-\mathrm{mL}$ cylindrical glass reactor [29], with water refrigeration using an ultra-thermostatic bath (Nova Técnica, Brazil). The cell was also equipped with a working electrode $\left(\mathrm{Ti} / \mathrm{TiO}_{2}\right.$ or $\mathrm{Ti} / \mathrm{TiO}_{2}$ coated with $\left.\left[\mathrm{Cu}_{2}(\mathrm{asp})_{4}\right]\right)$, an auxiliary electrode (Pt gauze), and an $\mathrm{Ag} / \mathrm{AgCl}(3 \mathrm{M} \mathrm{KCl})$ reference electrode. The photoanode was illuminated with a $125-\mathrm{W}$ Philips medium pressure mercury lamp $\left(I=9.23 \mathrm{~W} \mathrm{~m}^{-2}\right)$ without the glass, inserted in a quartz bulb.

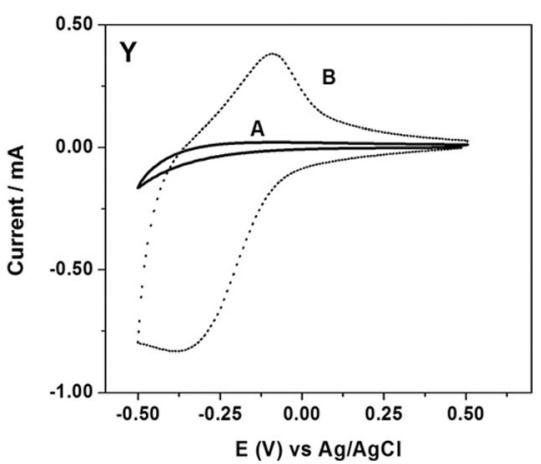

cyclic voltammograms obtained for $\mathrm{Ti} / \mathrm{TiO}_{2}-\mathrm{NT}$ electrode prior to $(A)$ and following $(B)$ modification with $\left[\mathrm{Cu}_{2}(\operatorname{asp})_{4}\right]$ and transferred to a solution containing $0.015 \mathrm{~mol} \mathrm{~L}^{-1} \mathrm{NaCl}$. Scan rate $=50 \mathrm{~m} \mathrm{~V} \mathrm{~s}^{-1}$ 
Fig. 3 Scanning electron microscope (SEM) images for Ti/ $\mathrm{TiO}_{2}$ electrode (a) and $\mathrm{Ti} / \mathrm{TiO}_{2}$ electrode decorated with $\left[\mathrm{Cu}_{2}(\mathrm{asp})_{4}\right]$ complex (b)
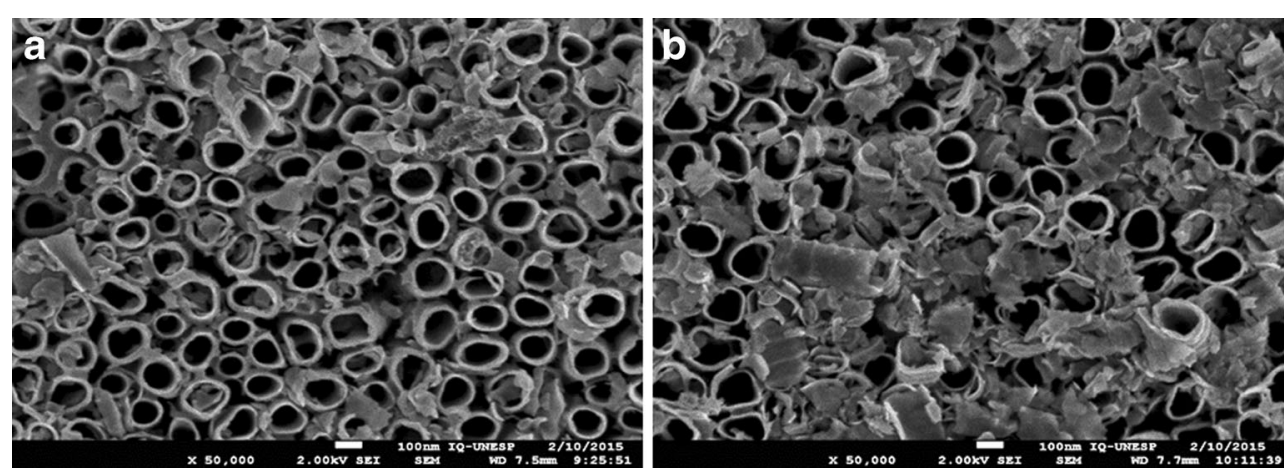

\section{Results and Discussion}

\section{Characteristics of the $\mathrm{Ti} / \mathrm{TiO}_{2}$ Electrode Decorated with $\left[\mathrm{Cu}_{2}(\operatorname{asp})_{4}\right]$ Complex}

Figure 2 (curve $\mathrm{X}$ ) illustrates the multi-scan (100 cycles) profile of the nanotube $\mathrm{Ti} / \mathrm{TiO}_{2}$ electrode when immersed in a solution of $5.0 \times 10^{-4} \mathrm{~mol} \mathrm{~L}^{-1}\left[\mathrm{Cu}_{2}(\operatorname{asp})_{4}\right]$ in $0.1 \mathrm{~mol} \mathrm{~L}^{-1}$ $\mathrm{NaCl}$ at $\mathrm{pH} 4$. The cyclic voltammograms present both reduction peaks at $-0.15 \mathrm{~V}$ attributed to the reduction of $\mathrm{Cu}$ (II) to $\mathrm{Cu}(\mathrm{I})$ in the complex and reoxidation at $+0.15 \mathrm{~V}$, respectively, in the reverse scan. The increase of both peak currents during successive scans suggests that the complex is deposited on electrode surface during scan within the range of +0.50 to $-0.50 \mathrm{~V}$. Aiming at attaining a relatively higher adherence on the electrode surface, the $\mathrm{Ti} / \mathrm{TiO}_{2}-\mathrm{NT}$ electrode was gently washed and transferred to a voltammetric cell containing only $0.015 \mathrm{~mol} \mathrm{~L}^{-1}$ of $\mathrm{NaCl}$, where the complex is less soluble. This behavior indicates that $\left[\mathrm{Cu}_{2}(\operatorname{asp})_{4}\right]$ is gradually incorporated into $\mathrm{TiO}_{2}-\mathrm{NT}$, forming a film where $\mathrm{Cu}$ (II) is reduced to $\mathrm{Cu}(\mathrm{I})$ at $-0.40 \mathrm{~V}$ and reoxidized to $\mathrm{Cu}(\mathrm{II})$ at $-0.10 \mathrm{~V}$ in a similar way as the one obtained in solution, though with a slight shifting of the potential to more negative regions. The cyclic voltammogram when compared to a bare electrode clearly indicates that without the copper complex, the Ti/ $\mathrm{TiO}_{2}$ behavior is similar to a typical semiconductor in the dark (Fig. 2, curve $Y(A)$ ). Successive scans failed to promote any decrease in the peak current, indicating the stability nature of the complex on the electrode surface.

\section{Curves of Photocurrent}

Figure 4a shows a comparison of photocurrent vs potential curves recorded for $\mathrm{Ti} / \mathrm{TiO}_{2}$ electrode decorated with $\left[\mathrm{Cu}_{2}(\operatorname{asp})_{4}\right]$, in the dark (1) and under UV/Vis illumination (2), and for $\mathrm{Ti} / \mathrm{TiO}_{2}$ electrode under dark (3) and UV/Vis irradiation (4) in $0.015 \mathrm{~mol} \mathrm{~L}^{-1} \mathrm{NaCl}$ solution, with a scan rate of $10 \mathrm{mV} \mathrm{s}^{-1}$. The curves (3) and (4) of Fig. 4a compares the bare electrode of Ti/ $\mathrm{TiO}_{2}$ in the dark and under UV/Vis irradiation, respectively. At a positive potential above $-0.25, \mathrm{Ti} / \mathrm{TiO}_{2}$ is seen to exhibit the occurrence of a photocurrent of around $2.5 \mathrm{~mA}$. This value is duplicated when the electrode is coated with the complex. In addition, the reduction of $\mathrm{Cu}$ (II) in the complex is seen at around $-0.40 \mathrm{~V}$ for $\mathrm{Ti} / \mathrm{TiO}_{2}$ coated with the complex in the dark, which is increased and shifted to $-0.60 \mathrm{~V}$ when the $\mathrm{Ti} / \mathrm{TiO}_{2}-\left[\mathrm{Cu}_{2}(\mathrm{asp})_{4}\right]$ electrode is irradiated by $\mathrm{UV} /$ a

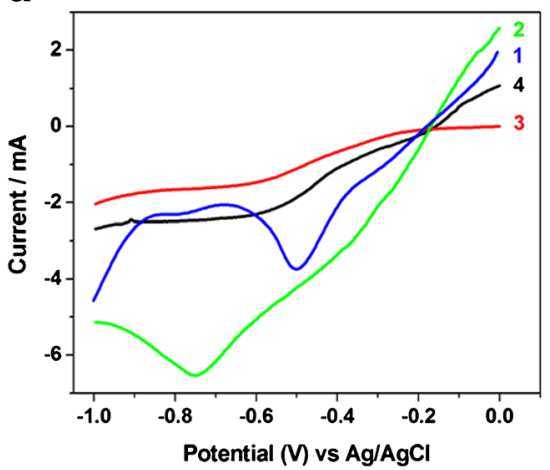

Fig. 4 a Linear voltammetry curves registered for $\mathrm{Ti} / \mathrm{TiO}_{2}$ electrode decorated with $\left[\mathrm{Cu}_{2}(\mathrm{asp})_{4}\right]$, in the dark (1) and under $\mathrm{UV} / \mathrm{Vis}$ illumination (2), and for $\mathrm{Ti} / \mathrm{TiO}_{2}$ electrode under dark (3) and UV/Vis irradiation (4), $\nu=10 \mathrm{mV} \mathrm{s}^{-1}$. b Linear voltammetry curves registered for $\mathrm{Ti} / \mathrm{TiO}_{2^{-}}$ b

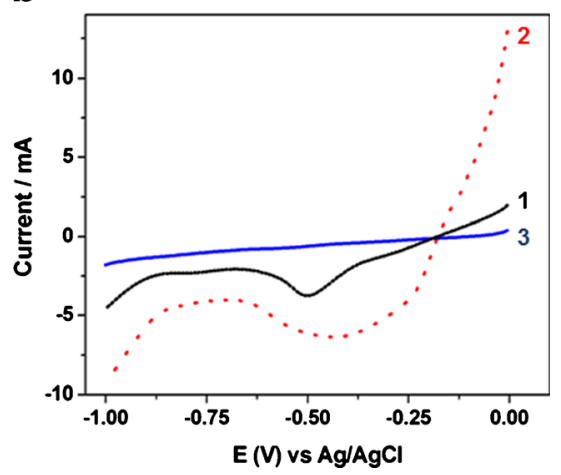

$\left[\mathrm{Cu}_{2}(\operatorname{asp})_{4}\right]$ in the dark $(1)$ and under UV/Vis illumination (2), and for $\mathrm{Ti}^{2} / \mathrm{TiO}_{2}$ under dark (3) in solution of $1.15 \mathrm{~mol} \mathrm{~L}^{-1}$ nitrite in $0.015 \mathrm{~mol} \mathrm{~L}^{-1}$ $\mathrm{NaCl}$. Scan rate $=10 \mathrm{mV} \mathrm{s}^{-1}$ 
Vis light. The results demonstrate that thin films of the $\left[\mathrm{Cu}_{2}(\text { asp })_{4}\right]$ complex on the $\mathrm{Ti} / \mathrm{TiO}_{2}$ could be acting as electron trap of the charges $\left(\mathrm{e}^{-} / \mathrm{H}^{+}\right)$generated under UV/irradiation. This behavior, in effect, indicates that light absorbed by the $\mathrm{Ti} / \mathrm{TiO}_{2}$ layer $(3.2 \mathrm{eV})$ produces electron-hole pairs, and the excited electrons are driven to the electrolyte interface via the conduction band, where $\mathrm{Cu}(\mathrm{II})$ in the complex is reduced to $\mathrm{Cu}(\mathrm{I})$. Upon UV irradiation, the large anodic photocurrent on the electrode decorated by the complex reflects the arising flux of electrons reaching the electrode surface, which has a reductive power capable of reducing nitrite indirectly and preferentially to water.

\section{Scanning Electron Microscope}

Figure 3a shows the scanning electron microscope (SEM) images for $\mathrm{Ti} / \mathrm{TiO}_{2}$, where uniform nanotube growth is observed over the entire substrate with a diameter of $100 \pm 10 \mathrm{~nm}$ and an average wall thickness of $10 \mathrm{~nm}$. Figure $3 b$ illustrates the deposits of the complex on the electrode surface, both between and inside the tubes showing that the $\mathrm{Ti} / \mathrm{TiO}_{2}$ is decorated by the complex. Upon calculation, the band gaps of $\mathrm{Ti} / \mathrm{TiO}_{2}-\mathrm{NTs}$ and $\mathrm{Ti} /$ $\mathrm{TiO}_{2}-\left[\mathrm{Cu}_{2}(\mathrm{asp})_{4}\right]$ were found to be 3.20 and $3.07 \mathrm{eV}$, respectively. These results indicate that the $\left[\mathrm{Cu}_{2}(\mathrm{asp})_{4}\right]$ complex was indeed decorated on the surface of $\mathrm{Ti} /$ $\mathrm{TiO}_{2}$-NTs, which is in line with the SEM results.

In an attempt to confirm this behavior, Fig. 4b illustrates the reduction of $1.15 \mathrm{~mol} \mathrm{~L}^{-1}$ nitrite in
$0.015 \mathrm{~mol} \mathrm{~L}^{-1} \mathrm{NaCl}$ solution on $\mathrm{Ti} / \mathrm{TiO}_{2}$-NTs decorated with $\left[\mathrm{Cu}_{2}(\mathrm{asp})_{4}\right]$ under dark (1) and UV-Vis irradiation (2). For comparison purposes, the same behavior is shown on the $\mathrm{Ti} / \mathrm{TiO}_{2}$ electrode (3). The linear scan voltammograms indicated that although there is no nitrite reduction in $\mathrm{Ti} / \mathrm{TiO}_{2}$, a well-defined signal at $-0.42 \mathrm{~V}$ is seen at dark conditions on the decorated electrode modified by the metallic complex. This wave is attributed to $\mathrm{Cu}(\mathrm{II}) /$ $\mathrm{Cu}(\mathrm{I})$ reduction on the electrode surface, which is evidenced by the increase observed (2, Fig. $4 b$ ) under UVVis irradiation. This behavior is indicative that under UV irradiation, the $\left[\mathrm{Cu}_{2}(\mathrm{asp})_{4}\right]$ deposited on the electrode surface of $\mathrm{Ti} / \mathrm{TiO}_{2}$-NTs acts as a trap of photogenerated electrons, which catalyzes the nitrite reduction.

The photoelectrochemical behavior of the $\mathrm{Ti} / \mathrm{TiO}_{2}-\left[\mathrm{Cu}_{2}(\mathrm{asp})_{4}\right]-$ decorated electrode is summarized in Fig. 5. When Ti/ $\mathrm{TiO}_{2}-\left[\mathrm{Cu}_{2}(\operatorname{asp})_{4}\right]$ is irradiated, photogenerated electrons on the $\mathrm{Ti} / \mathrm{TiO}_{2}$ are promoted from the valence band to the conduction band, leaving holes in the former. The photogenerated electrons easily reach the substrate surface and are trapped by $\mathrm{Cu}$ (II) in the complex decorating the $\mathrm{TiO}_{2}$ surface. The complex acts as a mediator, where nitrite is reduced to nitrogen species while $\mathrm{Cu}$ (II) is concomitantly reduced to $\mathrm{Cu}(\mathrm{I})$ in the complex. Following nitrite reduction, the holes were found to promote the reoxidation of $\mathrm{Cu}(\mathrm{I})$ to $\mathrm{Cu}(\mathrm{II})$, while at the same time regenerating the complex on the electrode surface. Thus, these results lead us to conclude that the electrode under investigation has stable behavior besides the fact that it plays an indirect role in the improvement of the nitrite reduction.

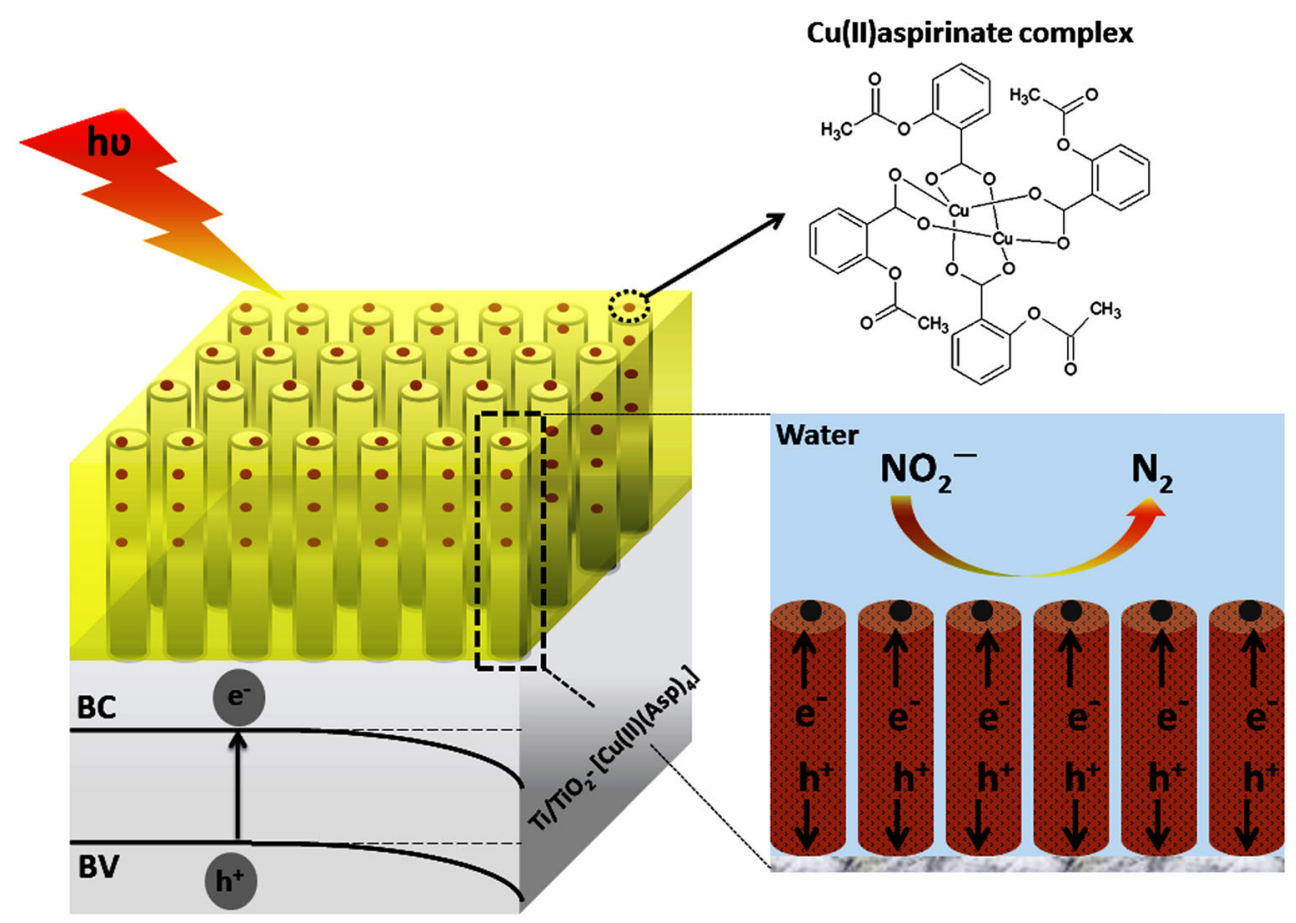

Fig. 5 Nitrite reduction by $\mathrm{Ti} / \mathrm{TiO} 2 \mathrm{NTs}$ with $\mathrm{Cu}(\mathrm{II})$ aspirinate complex 


\section{Removal of Nitrite by Photoelectrocatalyis, Photocatalysis, and Electrolysis}

Photoelectrolysis for $2.30 \mathrm{~mol} \mathrm{~L}^{-1}$ of $\mathrm{NO}_{2}{ }^{-}$in $0.015 \mathrm{~mol} \mathrm{~L}^{-1}$ $\mathrm{NaCl}$ under applied potential of $-0.60 \mathrm{~V}$ and UV/Vis irradiation was carried out for $\mathrm{Ti} / \mathrm{TiO}_{2}-\left[\mathrm{Cu}_{2}(\mathrm{asp})_{4}\right]$ electrode and compared with $\mathrm{Ti} / \mathrm{TiO}_{2}$ bare electrode as depicted in Fig. 6, curves $\mathrm{D}$ and $\mathrm{E}$, respectively. The results indicated that the reduction of nitrite by photoelectrocatlysis on the $\mathrm{Ti} /$ $\mathrm{TiO}_{2}-\left[\mathrm{Cu}_{2}(\text { asp })_{4}\right]$ electrode reached $40 \%$ while $25 \%$ was attained on the bare $\mathrm{Ti} / \mathrm{TiO}_{2}$ electrode.

Figure 6 also compares the removal of nitrite during $60 \mathrm{~min}$ of treatment on $\mathrm{Ti} / \mathrm{TiO}_{2}-\left[\mathrm{Cu}_{2}(\mathrm{asp})_{4}\right]$ electrode subjected to (A) photolysis (only UV/Vis irradiation), (B) electrolysis ( $E_{\text {app }}=-0.2 \mathrm{~V}$, without irradiation), (C) photocatalysis (UV/ Vis irradiation semiconductor), and (D) photoelectrocatalysis $\left(E_{\text {app }}=-0.2 \mathrm{~V}+\mathrm{UV} / \mathrm{Vis}\right.$ irradiation $)$. The results obtained showed that $40 \%$ of nitrite is reduced by photoelectrocatalytic following $60 \mathrm{~min}$ of treatment. Nevertheless, only 22, 10, and $9 \%$ of nitrite removal was reached in the photocatalytic, electrocatalytic, or photolytic treatments, respectively. These results undoubtedly illustrate the superior effectiveness of the photoelectrocatalytic procedure over the sum of the photocatalytic and electrochemical effects when it comes to nitrite reduction. By applying a bias potential, one significantly increases the efficiency of the photocatalytic activity of the $\mathrm{Ti}$ / $\mathrm{TiO}_{2}-\left[\mathrm{Cu}_{2}(\mathrm{asp})_{4}\right]$ electrode. The reaction rate of nitrite reduction was estimated from curves $\ln \left(\mathrm{C} / \mathrm{C}_{0}\right)$ vs time $(\mathrm{s})$. A linear relationship was obtained by using the techniques of photolysis, electrolysis, photocatalysis, and photoelectrocatalysis, indicating a removal following a first order kinetics. The respective values of the reduction rate constants $(\mathrm{k})$ were $3.2 \times 10^{-5}, 4.0 \times 10^{-5}, 7.6 \times 10^{-5}$, and $1.7 \times 10^{-4} \mathrm{~s}^{-1}$, confirming that nitrite reduction under photoelectrocatalysis is almost twice as in photocatalysis. Figure 6 curve F confirms

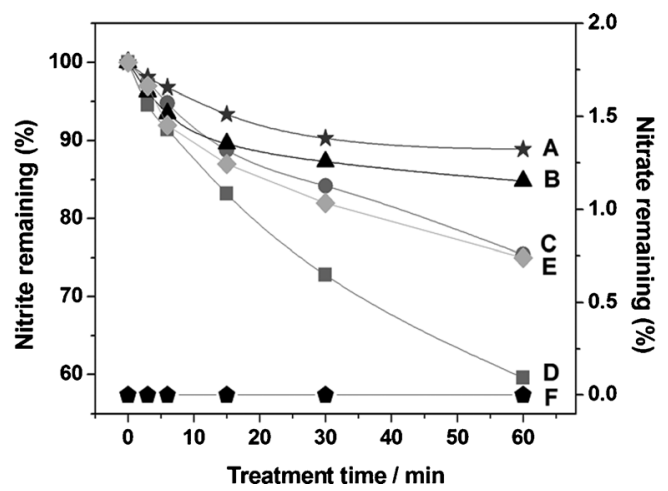

Fig. 6 Removal of $2.30 \mathrm{~mol} \mathrm{~L}^{-1}$ nitrite in $0.015 \mathrm{~mol} \mathrm{~L}^{-1} \mathrm{NaCl}$, pH 6 on $\mathrm{Ti} / \mathrm{TiO}_{2}-\left[\mathrm{Cu}_{2}(\mathrm{asp})_{4}\right]$ electrode by $(A)$ photolysis, $(B)$ electrolysis, $(C)$ photocatalysis, $(D)$ photoelectrocatalysis, and $(E)$ photoelectrocatalysis on $\mathrm{Ti} / \mathrm{TiO}_{2}$. $(F)$ Nitrate formation during the photoelectrocatalysis experiment that there is no formation of nitrate in the process, which implies that nitrite is reduced to other nitrogen species.

For the purpose of obtaining more information about the photoelectrocatalytic process and optimizing the method for nitrite removal, we also investigated other parameters controlling this process such as the nature of supporting electrolyte, the $\mathrm{pH}$ of the solution, the applied voltage, and the nitrite concentration.

\section{Effect of Applied Potential}

By virtue of checking the importance of selecting the best potential for promoting nitrite reduction, experiments were conducted using $2.30 \mathrm{~mol} \mathrm{~L}^{-1}$ of nitrite treated for $60 \mathrm{~min}$ on $\mathrm{Ti} / \mathrm{TiO}_{2}-\left[\mathrm{Cu}_{2}(\mathrm{asp})_{4}\right]$ electrode subjected to $\mathrm{UV} / \mathrm{Vis}$ irradiation and applied potential of $-0.20,-0.40$, -0.60 , and $-0.80 \mathrm{~V}$ vs $\mathrm{Ag} / \mathrm{AgCl}$. The nitrite decay is shown in Fig. 7, curves A-D, respectively.

As calculated previously from the onset potential measurements, the flat-band potential for $\mathrm{Ti} / \mathrm{TiO}_{2}-\left[\mathrm{Cu}_{2}(\operatorname{asp})_{4}\right]$ at $\mathrm{pH}$ 6.0 in $0.015 \mathrm{~mol} \mathrm{~L}^{-1} \mathrm{NaCl}$ media is about $E_{\mathrm{fb}}=+0.14 \mathrm{~V}$ (measurement not shown here). All the applied potentials employed in this study are negative of this flat-band potential and contributed towards promoting the reduction of nitrite, indicating the potential gradient over the titanium film, resulting in an electric field, which keeps photogenerated charges apart, trapped by the $\mathrm{Cu}$ (II) in the complex. These results suggest that nitrite adsorption is enhanced and/or the generation and separation of electron/hole pairs are accelerated at $E_{\text {ap }}=-0.60 \mathrm{~V}$, where maximum nitrite reduction is obtained following $60 \mathrm{~min}$ of treatment. Interestingly enough though, at an applied potential of $-0.80 \mathrm{~V}$, a decrease is observed in the nitrite reduction rate (curve D, Fig. 7), which may be attributed to water reduction competition. In all further experiments, $-0.60 \mathrm{~V}$ was chosen as the best potential for investigating nitrite removal.

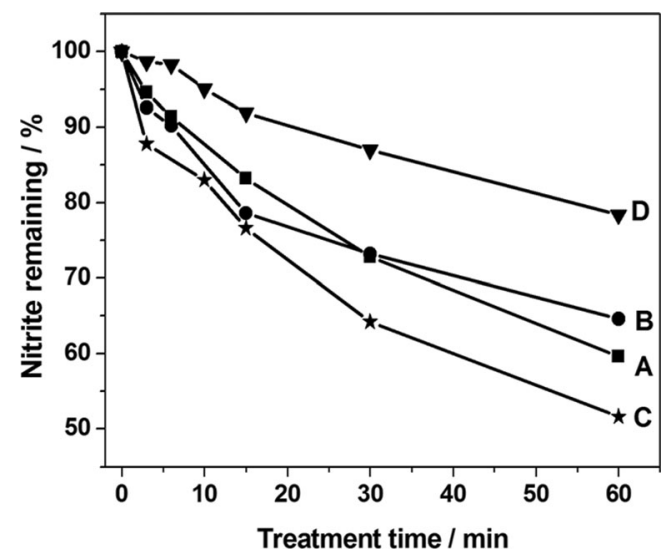

Fig. 7 Effect of applied potential in the reduction of $2.3 \mathrm{~mol} \mathrm{~L}^{-1}$ of nitrite by photoelectrocatalysis in $0.015 \mathrm{~mol} \mathrm{~L}^{-1}$ of $\mathrm{NaCl}, \mathrm{pH} 6$ on $\mathrm{Ti} / \mathrm{TiO}_{2^{-}}$ $\left[\mathrm{Cu}_{2}(\mathrm{asp})_{4}\right]$ nanotube electrode. Applied potential: $(A)-0.2,(B)-0.4$, $(C)-0.6$, and $(D)-0.8 \mathrm{~V}$ vs $\mathrm{Ag} / \mathrm{AgCl}$ and $\mathrm{UV}$ irradiation 


\section{Effect of pH and Electrolyte Concentration}

The influence of $\mathrm{pH}$ on the nitrate removal was investigated testing the reduction of $2.30 \mathrm{~mol} \mathrm{~L}^{-1}$ of nitrite on $\mathrm{Ti}$ / $\mathrm{TiO}_{2}-\left[\mathrm{Cu}_{2}(\mathrm{asp})_{4}\right]$ photoanode in $0.015 \mathrm{~mol} \mathrm{~L}^{-1} \mathrm{NaCl} \mathrm{pH}$ $4.0,6.0$, and 8.0 , under $\mathrm{UV} / \mathrm{V}$ is irradiation and $E_{\text {app }}=-0.60 \mathrm{~V}$. It is worth pointing out that more alkaline or more acidic solution was avoided so as to maintain the stability of the complex. The results indicated that after $60 \mathrm{~min}$ of treatment, $50 \%$ of nitrite was reduced in all the $\mathrm{pH}$ selected while the initial constant rate obtained for each solution was found to be slightly similar, presenting values around $1.4 \times$ $10^{-6} \mathrm{~s}^{-1}$. Similar results were obtained in $\mathrm{NaCl}$ or $\mathrm{Na}_{2} \mathrm{SO}_{4}$ and $\mathrm{NaCl}$ was adopted as supporting electrolyte for easy monitoring by ionic chromatography. In addition, further studies were carried out for three concentrations of $\mathrm{NaCl}$ as supporting electrolyte: $0.0070,0.0150$, and $0.0300 \mathrm{~mol} \mathrm{~L}^{-1}$. The results are slightly better in $0.015 \mathrm{~mol} \mathrm{~L}^{-1}$, chosen in further studies. No significant effect was seen in relation to nitrite removal as far as the $\mathrm{pH}$ of the original solution is concerned. In all further investigations, $\mathrm{pH} 6.0$ was selected as the optimum $\mathrm{pH}$ in the study of nitrite removal.

\section{Effect of Nitrite Concentration}

The influence exerted by the initial concentration of nitrite ( 0.23 to $2.30 \mathrm{~mol} \mathrm{~L}^{-1}$ ) over the photoelectrocatalytic efficiency was investigated by keeping all previously optimized parameters at a constant level in order to obtain the best performance of the photoelectrode. The results are shown in Fig. 8, curves A-D, respectively. At nitrite concentration of $2.30 \mathrm{~mol} \mathrm{~L}^{-1}$, the reduction process is found to be around $40 \%$ even after $60 \mathrm{~min}$ of treatment. These values are seen to diminish dramatically at lower concentration, reaching $100 \%$ for nitrite concentration of $0.23,0.46$, or $1.15 \mathrm{~mol} \mathrm{~L}^{-1}$. For clarity purposes, our study took into account the fact that has been pointed out in the literature [3, 4] which

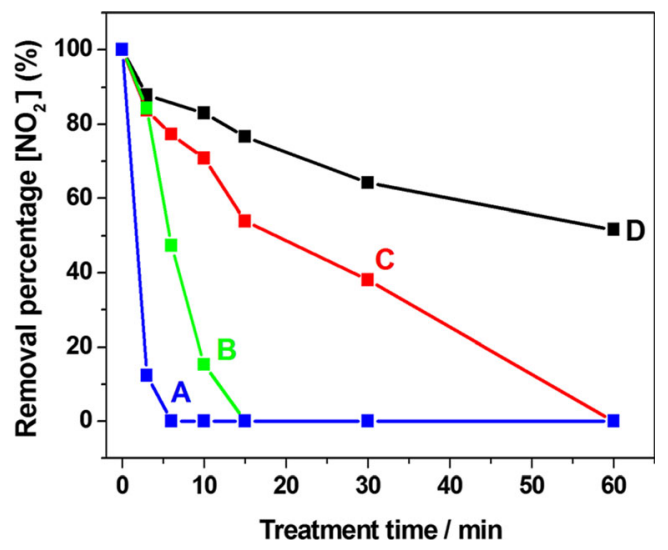

Fig. 8 Influence of concentration on the reduction of nitrite in $0.015 \mathrm{~mol} \mathrm{~L}^{-1} \mathrm{NaCl}, E_{\mathrm{app}}=-0.60 \mathrm{~V}+\mathrm{UV}$-Vis irradiation. $(A) 0.23,(B)$ 0.46 , (C) 1.15 , and $(D) 2.30 \mathrm{~mol} \mathrm{~L}^{-1}$ states that the occurrence of nitrite in natural water rarely exceeds the concentration of $1.0 \mathrm{mg} \mathrm{L}^{-1}$ nitrite. Thus in this case, a total reduction is observed in the treatment for water containing $0.23 \mathrm{~mol} \mathrm{~L}^{-1}$ of nitrite even after $7 \mathrm{~min}$ of treatment.

It is noteworthy the linear relationship observed between $\ln$ $\left(\mathrm{C} / \mathrm{C}_{0}\right)$ vs time (s) in all the nitrite levels under consideration during 60 min of treatment, with a calculated slope of $1.7 \times$ $10^{-4}, 5.3 \times 10^{-4}, 3.2 \times 10^{-3}$, and $1.1 \times 10^{-2} \mathrm{~s}^{-1}$, respectively, for $0.23,0.46,1.15$, and $2.30 \mathrm{~mol} \mathrm{~L}^{-1}$, bearing a typical behavior of a pseudo first-order reaction in nitrite reduction. The decrease in nitrite reduction rate at higher initial nitrite concentrations can be explained by the fact that at higher concentrations, the light intensity reaching the $\mathrm{Ti} / \mathrm{TiO}_{2}-\left[\mathrm{Cu}_{2}(\operatorname{asp})_{4}\right]$ film surface is reduced due to the lower transparency of the solution and/or the decrease in the ratio of the complex acting as mediator of electron transfer to the nitrite reduction, implying that the nitrite oxidation is to a larger extent dependent on the ratio $\left[\mathrm{Cu}_{2}(\operatorname{asp})_{4}\right] /[$ nitrite] in terms of concentration.

By so doing, through the use of best optimized experimental conditions of photoelectrocatalysis on $\mathrm{Ti} / \mathrm{TiO}_{2}-\left[(\mathrm{Cu})_{2} \mathrm{Asp}_{4}\right]$ electrode, the result was compared with that of $\mathrm{Ti} / \mathrm{TiO}_{2}$ bare electrode testing the reduction of $0.23 \mathrm{~mol} \mathrm{~L}^{-1}$ nitrite in $0.015 \mathrm{~mol} \mathrm{~L}^{-1} \mathrm{NaCl}$ applying a potential of $-0.60 \mathrm{~V}$ under UV/Vis irradiation. The results are shown in Fig. 9. In this experimental condition, both electrodes are found to reduce $100 \%$ of nitrite. However, on the decorated electrode, the time required for the removal of total nitrite residues is found to be three times lower compared to the bare electrode. The kinetic reduction follows a first-order reaction and the rate constant obtained is $0.0043 \mathrm{~s}^{-1}$ for $\mathrm{Ti} / \mathrm{TiO}_{2}-\left[(\mathrm{Cu})_{2} \mathrm{Asp}_{4}\right]$ and $0.011 \mathrm{~s}^{-1}$ for $\mathrm{TiO}_{2}$. Accordingly, further experiments were carried out in order to monitor the determination of ammonia and other species of nitrogen assigned here as nitrogen-containing species. Experiments over a 60-min period for $0.23 \mathrm{~mol} \mathrm{~L}^{-1}$ nitrite (A) were

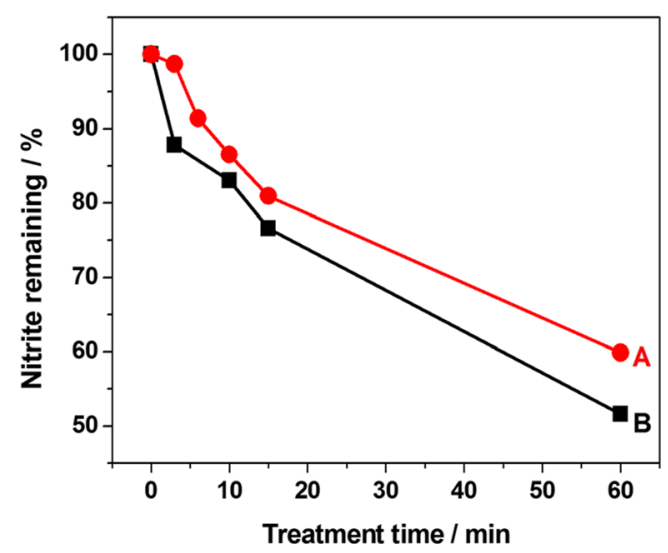

Fig. 9 Removal of $2.30 \mathrm{~mol} \mathrm{~L}^{-1}$ nitrite in $0.015 \mathrm{~mol} \mathrm{~L}^{-1} \mathrm{NaCl} . E=$ $-0.60 \mathrm{~V}+\mathrm{UV}-\mathrm{Vis}$ irradiation. (A) $\mathrm{Ti} / \mathrm{TiO}_{2}$ electrode and $(B) \mathrm{Ti} / \mathrm{TiO}_{2}-$ $\left[\mathrm{Cu}_{2}(\operatorname{asp})_{4}\right]$ electrode 


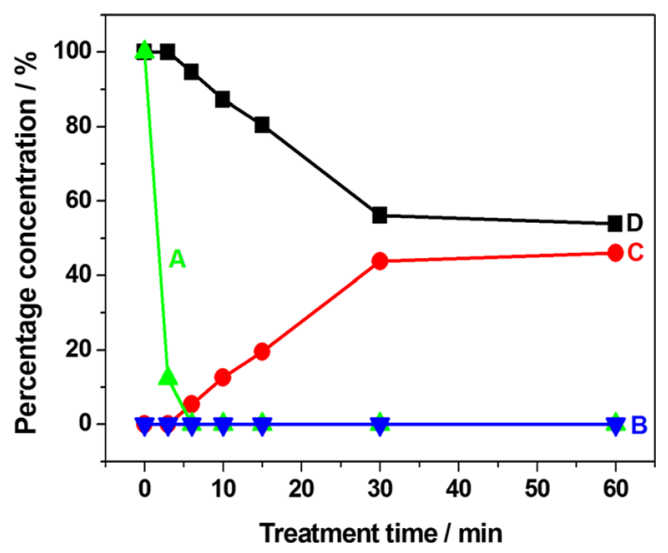

Fig. 10 Photoelectrocatalytic reduction of $0.23 \mathrm{~mol} \mathrm{~L}^{-1}$ of nitrite $(A)$ and concomitant evaluation of nitrate formation $(B)$, ammonia formation $(C)$, and nitrogen-containing gaseous species formation $(D)$

conducted, where we monitored the formation of nitrate (B) as well as the generation of dissolved ammonia (C) in $0.015 \mathrm{~mol} \mathrm{~L}^{-1} \mathrm{NaCl}$ on photoanode biased at $-0.6 \mathrm{~V}$ vs $\mathrm{Ag} / \mathrm{AgCl}$ under $\mathrm{UV} / \mathrm{Vis}$ irradiation. The results have been shown in Fig. 10. As observed, there is a gradual decrease of nitrite concentration over time and a concomitant increase in ammonium concentration as product of the nitrite reduction, according to the global reaction:

$\mathrm{NO}_{2}^{-}+8 \mathrm{H}^{+}+6 \mathrm{e}^{-} \Rightarrow \mathrm{NH}_{4}^{+}+2 \mathrm{H}_{2} \mathrm{O}$.

Furthermore, for the fact that no nitrate is detected clearly indicates the absence of oxidation process in the system under the optimized experimental condition. In line with reports in the literature [29], iron porphyrin complexes and complex of $\left[\left(\mathrm{NH}_{4}\right)_{2}\left[\mathrm{MoO}_{2}\left(\mathrm{O}_{2} \mathrm{CC}(\mathrm{S})\left(\mathrm{C}_{6} \mathrm{H}_{5}\right)_{2}\right)_{2}\right.\right.$ pave the way for the electrocatalytic reduction of nitrite to nitrous oxide and ammonia. Nitrite photoelectroreduction could also be converted into nitrogen and/or other nitrogen-containing gases (Eq. (2)):

$\mathrm{NO}_{2}{ }^{-}+4 \mathrm{H}^{+}+3 \mathrm{e}^{-} \Rightarrow 1 / 2 \mathrm{~N}_{2}+2 \mathrm{H}_{2} \mathrm{O}$.

The results indicate that following 60 min of photoelectrocatalysis, using $\mathrm{Ti} / \mathrm{TiO}_{2}-\left[\mathrm{Cu}_{2}(\operatorname{asp})_{4}\right], 56 \%$ of nitrite conversion to gaseous species and $42 \%$ of ammonia are observed. These results are seen to be a remarkably interesting outcome once no nitrate formation is observed. A further outcome that merits our attention lies in the fact that nitrite is not detectable in the solution after treatment up to levels of $0.5 \mathrm{mg} \mathrm{L}^{-1}$, as assigned by the detection limit of the ionic chromatographic method adopted here.

\section{Energy Consumption}

To evaluate the economic viability of the developed process, the total cost involved in the nitrite reduction was estimated by using Eq. (3) established by Bolton et al. [30] that establish standard figures of merit for the comparison of energy consumption independent of the nature of the system. The electrical energy per order $\left(E_{\mathrm{EO}}, \mathrm{kWh} / \mathrm{m}^{3} /\right.$ order) is the electric energy in kilowatt hours $[\mathrm{kWh}$ required to degrade a contaminant by one order of magnitude in a unit volume $\left(1 \mathrm{~m}^{3}\right)$ and it is used when the concentration of contaminant is low and the degradation follows a first-order kinetics.

$E_{E O}=\frac{P \times t \times 1000}{V \times \log \left(\text { Nitrite }_{i} / \text { Nitrite }_{f}\right)}$

where $P$ stands for the rated power $(\mathrm{kW})$ of the reduction system, $t$ being the treatment time (h), $V$ the treated volume (L), and Nitrite $_{i}$ and Nitrite $f$ are the initial and final concentrations of nitrite after a $t$ treatment time. The rated power is known to be equal to the sum of the individual energy consumption, the lamp, and the power supply. Thus, at optimized conditions for reduction of nitrite, energy costs for promoting the treatment using $\mathrm{Ti} / \mathrm{TiO}_{2}$ coated by thin films of $\left[\mathrm{Cu}(\mathrm{II})(\mathrm{asp})_{4}\right]$ and pure $\mathrm{TiO}_{2}$ were performed. The results showed that $56.8 \mathrm{kWh} \mathrm{m}^{-3}$ order $^{-1}$ is consumed for $\mathrm{Ti} /$ $\mathrm{TiO}_{2}-\left[\mathrm{Cu}(\mathrm{II})(\mathrm{asp})_{4}\right]$ and this value is increased to $157.61 \mathrm{kWh} \mathrm{m}^{-3}$ order $^{-1}$ for the bare $\mathrm{TiO}_{2}$ electrode after 6 min of treatment. The results indicate that the electrodes decorated presented an energy consumption by approximately 2.75 times lower than bare $\mathrm{TiO}_{2}$, emphasizing the importance of the complex presence inside and between the $\mathrm{TiO}_{2}$ tubes.

\section{Conclusions}

Our findings demonstrate that highly ordered nanotubes of Ti/ $\mathrm{TiO}_{2}$ can easily be decorated with copper(II) aspirinate by successive scan of cyclic voltammetry, and the modified electrode can be an excellent alternative for the removal of nitrite in drinking water via photoelectrocatalysis. The results suggest that $\mathrm{Ti} / \mathrm{TiO}_{2}$ coated by thin films of $\left[\mathrm{Cu}(\mathrm{II})(\mathrm{asp})_{4}\right]$ when irradiated by UV-Vis tended to promote electron transfer from the valence band to the conduction band, easily reaching the substrate surface while being trapped by $\mathrm{Cu}$ (II) in the complex. The complex acts as a mediator enabling the indirect reduction of nitrite to nitrogen species while concomitantly reducing $\mathrm{Cu}(\mathrm{II})$ to $\mathrm{Cu}(\mathrm{I})$ in the complex. The procedure is found to contribute meaningfully towards regenerating the complex likewise promoting total removal of nitrite (limit detection of $5 \mathrm{mg} \mathrm{L}^{-1}$ ). Taking into account that the maximum limit recommended for nitrite in drinking water is $1 \mathrm{mg} \mathrm{L}^{-1}$ (WHO), the proposed method could be successfully applied towards the removal of nitrite from drinking water. 
Acknowledgments The authors deem it a great honor and privilege to extend their heartfelt gratitude to the Brazilian Research Agencies-FAPESP (process no. 2015/18109-4) and CNPq (process 446245/2014-3, 310421/2013-6 and 152274/2016-2), for the financial support granted in the course of this research.

\section{References}

1. W.H. Organization, Guidelines for Drinking-Water Quality, 4th edn., 2011

2. U. E. P. Agency (2016), https://www.epa.gov/ground-water-anddrinking-water/table-regulated-drinking-water-contaminants

3. L. A. Ramos, C. C. S. Cavalheiro, and É. T. G. Cavalheiro, Quim. Nova 29, 1114 (2006)

4. G. Ellis, I. Adatia, M. Yazdanpanah, and S. K. Makela, Clin. Biochem. 31, 195 (1998), http://www.sciencedirect. com/science/article/pii/S0009912098000150

5. S. Oga, M. M. de A. Camargo, and J. A. de O. Batistuzzo, Fundamentos de Toxicologia, $4^{\mathrm{a}}$ Ed (São Paulo, 2008)

6. M. Shrimali and K. P. Singh, Environ. Pollut. (Barking, Essex : 1987) 112,351 (2001)

7. S. Ghafari, M. Hasan, and M. K. Aroua, Bioresource Technol. 99, 3965 (2008)

8. N. Barrabés and J. Sá, Appl. Catal. B: Environ. 104, 1 (2011)

9. C. L. Constantinou, C. N. Costa, and A. M. Efstathiou, Catal. Today $151,190(2010)$

10. A. Kapoor and T. Viraraghavan, J. Environ. Eng. 123, 371 (1997)

11. G. G. Bessegato, T. T. Guaraldo, J. F. de Brito, M. F. Brugnera, and M. V. B. Zanoni, Electrocatalysis 6, 415 (2015)

12. H. Zhang, G. Chen, and D. W. Bahnemann, J. Mater. Chem. 19, 5089 (2009)
13. I. Paramasivam, H. Jha, N. Liu, and P. Schmuki, Small (Weinheim an Der Bergstrasse, Germany) 8, 3073 (2012)

14. R. Daghrir, P. Drogui, and D. Robert, J. Photochem. Photobiol. A: Chem. 238, 41 (2012)

15. T. A. Egerton, J. Chem. Tech. Biotechnol. 86, 1024 (2011)

16. F. M. M. Paschoal, L. Nuñez, M. R. D. V. Lanza, and M. V. B. Zanoni, J. Adv. Oxid. Technol. 16, 63 (2013)

17. F. M. M. Paschoal, G. Pepping, M. V. B. Zanoni, and M. A. Anderson, Environ. Sci. Technol. 43, 7496 (2009)

18. Y. Matsumoto, J. Electrochem. Soc. 128, 1040 (1981)

19. F. A. Sayão, L. Nuñez, and M. V. B. Zanoni, J. Braz. Chem. Soc. $25,1153(2014)$

20. G. Loget, J. E. Yoo, A. Mazare, L. Wang, and P. Schmuki, Electrochem. Commun. 52, 41 (2015)

21. K. Lee, A. Mazare, and P. Schmuki, Chem. Rev. 114, 9385 (2014)

22. P. Roy, S. Berger, and P. Schmuki, Angew. Chem. (International Ed in English) 50, 2904 (2011)

23. T. Arai, S. Sato, K. Uemura, T. Morikawa, T. Kajino, and T. Motohiro, Chem. Commun. (Cambridge, England) 46, 6944 (2010)

24. R. Ramaraj, Proc. Indian Acad. Sci.-Chem. Sci. 108, 181 (1996)

25. T. Fujimori, S. Yamada, H. Yasui, H. Sakurai, Y. In, and T. Ishida, J. Biol. Inorg. Chem.: JBIC: A Publication of the Society of Biological Inorganic Chemistry 10, 831 (2005)

26. D. A. Williams, W. O. Foye, and D. T. Walz, J. Pharm. Sci. 65, 126 (1976)

27. J. C. Cardoso and M. V. Boldrin Zanoni, Sep Sci. Technol. 45, 1628 (2010)

28. J. C. Cardoso, T. M. Lizier, and M. V. B. Zanoni, Appl. Catal. B: Environ. 99, 96 (2010)

29. F. Vicente, J. J. Garcia-Jareño, R. Tamarit, A. Cervilla, and A. Domenech, Electrochim. Acta 40, 1121 (1995)

30. J. R. Bolton, K. G. Bircher, W. Tumas, and C. A. Tolman, Pure Appl. Chem. 73, 627 (2001) 